\title{
Rights-Based Approaches to Preventing, Detecting, and Responding to Infectious Disease
}

\author{
Benjamin Mason Meier, Dabney P. Evans, and Alexandra Phelan
}

Policymakers have come to look to human rights law in framing national health policy and global health governance. Human rights law offers universal frameworks to advance justice in public health, codifying international standards to frame government obligations and facilitate accountability for realising the highest attainable standard of health. Addressing threats to individual dignity as 'rights violations' under international law, health-related human rights have evolved dramatically to offer a normative framework for public health. Yet, public health efforts to address infectious disease continue to employ mechanisms that infringe individual rightsfrom the recent Ebola epidemics in Sub-Saharan Africa to the ongoing COVID-19 pandemic that threatens the world-with public health laws violating individual bodily integrity through vaccination and treatment mandates, violating individual medical privacy through surveillance and reporting, and violating individual liberty through quarantine and isolation. This chapter examines the implementation of human rights law in infectious disease control, analysing rights-based approaches to prevent, detect, and respond to infectious disease outbreaks.

Part I outlines the theoretical framework for health and human rights and describes evolving efforts to balance individual rights protections against government public

\author{
B. M. Meier $(\varangle)$ \\ Department of Public Policy, University of North Carolina at Chapel Hill, Chapel Hill, NC, USA \\ e-mail: bmeier@unc.edu \\ O’Neill Institute for National \& Global Health Law, Georgetown University, Washington, \\ DC, USA \\ D. P. Evans \\ Global Health at the Hubert Department of Health, Rollins School of Public Health, Emory \\ University, Atlanta, GA, USA
}

A. Phelan

Department of Law, Georgetown University Law School, Washington, DC, USA

Assistant Professor, Center for Global Health Security, Georgetown University, Washington, DC, USA 
health practices. Where human rights were long neglected in international health debates, early government reactions to the HIV/AIDS pandemic catalysed human rights as a basis for public health, as advocates looked explicitly to human rights as being 'inextricably linked' to public health efforts. Amidst the heightened fear and emerging advocacy that structured the early years of the AIDS response, policymakers sought to implement human rights law in public health policy-viewing discrimination as counterproductive to public health goals, abandoning coercive tools of public health practice, and applying human rights to focus on the individual risk behaviours leading to HIV transmission. Moving towards a focus on collective rights, viewing public health itself as a human right, these human rights claims have sought to address underlying population-level determinants of health in a rapidly globalising world.

These human rights have since come to hold a central place in framing public health policy, and Part II examines the ways in which these health-related human rights have been applied to realise non-discrimination and equality; autonomy, bodily integrity, and informed consent; participation; and the right to health. By recognising an inextricable linkage between public health and human rights, the health and human rights movement could move away from its early focus on the conflicts between public health practice and individual human rights, employing human rights promotion to advance public health goals. However, infectious disease control efforts continue to challenge the notion that individual rights are always the best approach to support population health, with recent responses to Ebola and COVID-19 continuing to rely on national policies that unnecessarily limit individual rights to protect public health. The human rights infringements resulting from these violative national policies highlight the continuing need for rights-based global health governance in preventing, detecting and responding to infectious disease.

In the new millennium, global health governance has sought to balance infectious disease imperatives for the public's health with individual dignity protections in human rights, and Part III analyses how global health law has framed this balance between public health and human rights. International law has long been seen as essential to the international cooperation necessary to address the global threat of infectious disease, but human rights were never addressed under global health law until the 2005 revision of the International Health Regulations. This 2005 revision explicitly looked to human rights for the first time-as a basis to respect human dignity and bodily integrity across states in the national implementation of infectious disease control measures. Despite this recent promise of universal human rights in global health governance, the 2014 development of the Global Health Security Agenda reverts to the 'securitisation' of public health to frame national efforts to prevent, detect, and respond to infectious disease. As nations again resort to unnecessary human rights infringements, abandoning global solidarity and international law in their emergency responses to the COVID-19 pandemic, it remains unclear how human rights law will be implemented through global health governance to support the future of infectious disease control.

This chapter concludes that the rights-based approach to infectious disease control has evolved—under human rights law, as applied to national policy, and in the 
development of global health governance-yet there remains little assessment of how these approaches either realise or infringe upon human rights in the pursuit of public health. Calling for a human rights research agenda to assess infectious disease control policies, programmes, and practices throughout infectious disease responses, this chapter proposes human rights monitoring of infectious disease control as a basis to facilitate accountability for the implementation of international human rights under global health law.

\section{Health and Human Rights}

Human rights law offers international frameworks to facilitate accountability for social justice in efforts to prevent, detect, and respond to infectious disease. Instrumental to human dignity, human rights address basic needs and frame individual entitlements, conceptualising international imperatives to uphold a universal vision of global justice. ${ }^{1}$ By addressing threats to dignity as 'rights violations,' international law offers global standards by which to frame government responsibilities and evaluate policies and outcomes under law, shifting the policy debate from political aspiration to legal obligation. ${ }^{2}$ Empowering individuals to seek accountability for these government obligations rather than serving as passive recipients of government benevolence, human rights law identifies individual rights-holders and their entitlements and corresponding duty-bearers and their obligations. ${ }^{3}$ The state becomes the principal duty-bearer of human rights upon ratification of the underlying international human rights treaty, with the government thereafter accepting resource-dependent obligations to 'progressively realise' a human right 'to the maximum of its available resources, with a view to achieving progressively the full realisation of the rights'. Building upon state obligations to realise the public's health, human rights can be seen both to protect individual rights from infringement in the pursuit of infectious disease control and to promote collective rights to underlying determinants of health.

\subsection{Responsibilities of the State for Public Health}

Public health encompasses the policies, programmes, and practices of a government to realise the collective rights of its peoples to health. Rather than focusing on the health of individuals, public health focuses on the health of societies. ${ }^{5}$ At its most

\footnotetext{
${ }^{1}$ Donnelly (2003).

${ }^{2}$ Gostin (2014).

${ }^{3}$ Steiner et al. (2008).

${ }^{4}$ UN General Assembly, 'International Covenant on Civil and Political Rights' (Res. 2200A (XXI), 16 December 1966) art. 2; Felner (2009).

${ }^{5}$ Rose et al. (1999).
} 
basic, '[p]ublic health is what we, as a society, do collectively to assure the conditions for people to be healthy'. ${ }^{6}$ States have long recognised a responsibility to protect their peoples from infectious disease threats, ${ }^{7}$ developing varied approaches of what must be done at a population level to assure 'underlying determinants of health' ${ }^{8}$ Whereas medicine focuses primarily on individual curative treatments in clinical settings, public health actions protect and promote ${ }^{9}$ the health of entire societies by using multi-disciplinary interventions and multi-sectoral approaches to address the economic, political, and social determinants that underlie the public's health. ${ }^{10}$ Under this expansive view, public health responds to the fundamental underlying structures affecting health, involving, inter alia, disease outbreaks, demographic patterns, economic distributions, and deleterious behaviours. In meeting these collective challenges, public health approaches are often designed to achieve 'the greatest good for the greatest number', applying a utilitarian lens as a basis to control the spread of infectious disease. ${ }^{11}$

\subsection{Individual Rights in Tension with Public Health}

Where human rights protect the individual, these individual rights are often seen to be in tension with state responsibilities to protect the public's health. Public health, in ensuring that societies can be healthy, often includes government intervention to restrict individual rights to protect the general welfare. In this conflict between collective benefit and individual restrictions, policymakers have long grappled with the appropriate balance between individual rights protection and public health promotion. In the development of human rights law, World War II showed the world the horrors that could occur under the guise of public health, and human rights would be codified under the post-war United Nations (UN) as a means to prevent public health authorities from infringing individual human rights. Out of this UN development of human rights law to protect individuals from public health practices, scholars and practitioners in the 1980s came to recognise the 'inextricable linkages' between public health and human rights, examining the ways in which the public health lens and human rights paradigm can complement each other in preventing disease and promoting health.

\footnotetext{
${ }^{6}$ The Institute of Medicine (1988) 19; see also Brockington (1968).

${ }^{7}$ Fidler (2002).

${ }^{8}$ Gostin (2001).

${ }^{9}$ Raeburn and Macfarlane (2003).

${ }^{10}$ Beaglehole and Bonita (1997).

${ }^{11}$ Holland (2015).
} 


\subsubsection{Birth of Human Rights in Response to the Public Health State}

The notion of human rights under international law as a basis for public health finds its roots in the horrors that occurred during World War II and the standards laid down by the war tribunals that followed. ${ }^{12}$ International human rights law was seen as a direct response to public health actions that infringed on individual liberties during the war. In articulating health-related human rights, the so-called 'Doctors Trial' of Nazi health practitioners by the International Military Tribunal at Nuremberg formed a key foundation for early post-war human rights developments. ${ }^{13}$

The atrocities committed by Nazi physicians during World War II, enabled by the German public health establishment, reflected a complete disregard for the value of human life and the inherent dignity of research subjects. ${ }^{14}$ Beginning in 1933, the German Reich advanced public health theories of eugenics as the basis for promulgating the Law for the Prevention of Genetically Diseased Offspring, which outlined processes for the voluntary and mandatory sterilization of myriad 'hereditary defects'. ${ }^{15}$ Pursuant to these so-called 'racial hygiene' programmes, German public health physicians sterilized between 300,000 and 400,000 German citizens prior to the war. ${ }^{16}$ At the onset of war, the Nazi medical establishment moved from the sterilization to the killing those deemed to be 'incurably ill' ${ }^{17}$ During the war, with eugenics holding widespread acceptance in the state medical establishment, German physicians voluntarily aided in theorizing, planning, and operating Nazi killing programmes, which had then expanded from patients of German state hospitals to inmates of Nazi concentration camps. ${ }^{18}$ Founded upon debased notions of public health, physicians exterminated millions to prevent the spread of purported diseases and defects. ${ }^{19}$ Rather than questioning the ethical propriety of their actions, Nazi physicians enthusiastically performed acts of genocide, acting under a strong, albeit perverse, belief that they were working in accordance with the sound medical principle of 'healing the state'. ${ }^{20}$ The genocidal horrors and human experimentation of the Holocaust would not have been possible without the professional legitimation and direct participation of the public health establishment.

Given these wanton violations of individual life and liberty in the course of the War, human rights, inhering in every individual simply by virtue of being human, would become the cornerstone of the post-war world. The Doctors Trial of 19461947, in which U.S. judges at Nuremberg passed judgment on Nazi physicians and health workers, would mark the first international criminal prosecution of health

\footnotetext{
${ }^{12}$ Moyn (2010).

${ }^{13}$ Annas and Grodin (1992).

${ }^{14}$ See Taylor (1992).

${ }^{15}$ Lippman (1993).

${ }^{16}$ Sidel (1996).

${ }^{17}$ Lippman (1992).

${ }^{18}$ Barondess (1996).

${ }^{19}$ Lippman (1992).

${ }^{20}$ Malinowski (2003).
} 
workers for 'crimes against humanity', uncovering widespread patient and subject harms that would come to be seen as violations of human rights. ${ }^{21}$ Rebuilding a world out of the ashes of World War II, every human being would be seen as equal in dignity and rights, with these human rights serving as a protection against state public health actions.

\subsubsection{Derogation from Individual Rights to Protect Public Health}

Notwithstanding this primacy of individual dignity and rights, international law supports the derogation of certain individual rights to protect the public's health. Where a right is considered derogable (capable of being temporarily suspended), the protection of public health is seen as a legitimate reason for government interference to promote the general welfare. ${ }^{22}$ In clarifying the derogation of human right to protect public health, the evolution of international human rights law has sought to: define which rights are derogable, limit the grounds for rights derogation, and outline the processes of derogating rights.

Beginning with the 1948 Universal Declaration of Human Rights (UDHR), states agreed that '[e]veryone shall be subject only to such limitations as are determined by law solely for the purpose of securing due recognition and respect for the rights and freedoms of others.... ${ }^{23}$ Translating this non-binding declaration into international treaty law, the 1966 International Covenant on Civil and Political Rights (ICCPR) articulated the grounds for human rights derogation, stipulating that an '[o]fficial proclamation of public emergency allows deviation from other obligations to the extent required'. ${ }^{24}$ These derogable rights would be specified in the context of a public health emergency, noting that the 'right to liberty of movement is...subject to restrictions necessary to protect public health or morals or the rights and freedoms of others' ${ }^{25}$ The ICCPR would thus specify three principal grounds for derogation:

1. To secure due recognition and respect for the rights and freedoms of others;

2. To meet the just requirements of morality, public order, and the general welfare; or

3. In time of emergency, where there are threats to the vital interests of the nation.

\footnotetext{
${ }^{21}$ Annas and Grodin (1992).

${ }^{22}$ Gostin and Mann (1994).

${ }^{23}$ UN General Assembly, 'Universal Declaration of Human Rights' (Res. 217 A (III), 10 December 1948) art. 29.

${ }^{24}$ UN General Assembly, 'International Covenant on Civil and Political Rights' (Res. 2200A (XXI), 16 December 1966) art. 4.

${ }^{25}$ UN General Assembly, 'International Covenant on Civil and Political Rights' (Res. 2200A (XXI), 16 December 1966) art. 12.
} 
As states came to recognise that "public health may be invoked as a ground for limiting certain rights', ${ }^{26}$ scholars developed a set of principles to assure that such limitations on rights occur only 'in narrowly defined circumstances', holding that such human rights infringements only be undertaken:

1. When applied as a last resort;

2. When prescribed by law (i.e., not imposed arbitrarily);

3. When related to a compelling public interest (e.g., protection of public health); and

4. When found to be necessary, proportional to the public interest, and without less intrusive or restrictive measures available. ${ }^{27}$

Balancing the societal benefit to public health against the state infringement of individual rights, various legal scholars have sought to develop balancing tests to understand the specific circumstances in which it is necessary to restrict human rights to protect public health. These 'human rights impact assessments' have sought to measure the human rights impacts of public health policies and scrutinise disease prevention efforts to:

1. Clarify the public health purpose, narrowing public health goals to avoid overburdening rights;

2. Evaluate likely policy effectiveness, questioning whether the means undertaken will achieve the public health purpose;

3. Determine whether the public health policy is well targeted, recognizing the dangers of over-inclusiveness; and

4. Examine each public health policy for possible human rights burdens, looking to (1) the nature of the human right, (2) the invasiveness of the intervention, (3) the frequency and scope of the infringement, and (4) its duration. ${ }^{28}$

\subsubsection{Recognizing the "Inextricable Linkages" Between Public Health and Human Rights}

Reversing a history of neglect for human rights in international health debates throughout the height of the Cold War, the advent of the AIDS response operationalised human rights as a foundation for public health, as scholars and advocates looked explicitly to human rights law in framing public health practice. Governments had initially sought to react to the emergent threat of AIDS through traditional infectious disease practices-including compulsory testing, named reporting,

\footnotetext{
${ }^{26}$ UN Commission on Human Rights, 'The Siracusa Principles on the Limitation and Derogation Provisions in the International Covenant on Civil and Political Rights (UN Doc E/CN.4/1985/4, 1984) art. 25.

${ }^{27}$ UN Commission on Human Rights, The Siracusa Principles on the Limitation and Derogation Provisions in the International Covenant on Civil and Political Rights, UN Doc. E/CN.4/1985/4, 28 September 1984.

${ }^{28}$ Gostin and Mann (1994).
} 
travel restrictions, isolation and quarantine, and other rights derogations-yet human rights were seen as a protection against these intrusive government infringements on individual liberty and a bond for stigma-induced cohesion among HIV-positive activists. ${ }^{29}$ In this period of emerging rights-based activism, Jonathan Mann's tenure at the World Health Organisation (WHO) marked a turning point in the application of individual human rights to public health policy, viewing discrimination and coercion as counterproductive to public health goals and applying human rights to focus attention on the individual risk behaviours leading to HIV transmission. ${ }^{30}$ Mann's vocal leadership of the WHO Global Programme on AIDS, formally launched in 1987, shaped formative efforts to create a rights-based framework for global health governance and national health policy. ${ }^{31}$ Drawing from international human rights standards, public health policies came to stress the need for risk reduction programs to respect and protect human rights as a means to achieve the individual behaviour change necessary to reduce HIV transmission. ${ }^{32}$

In looking beyond individual behaviours in the HIV/AIDS response, Mann sought to extend the promise of human rights in addressing underlying population-level determinants of health - viewing rights realisation as supportive of 'a broader, societal approach to the complex problem of human wellbeing' ${ }^{33}$ Mann cautioned that HIV would inevitably descend the social gradient, calling for the rights-based examination of socioeconomic, racial, and gender inequities in abetting the spread of the disease. ${ }^{34}$ Through this consideration of the collective determinants of vulnerability to HIV infection-rejecting the paradigm of complete individual control for health behaviours, a basic premise of the individual rights framework - the health and human rights movement shifted away from its early focus on the conflicts between public health responsibilities and human rights obligations. ${ }^{35}$ Out of this recognition of a mutually-reinforcing linkage between public health and human rights, Mann proposed a tripartite framework to describe the effects of (1) human rights violations on health, (2) public health policies on human rights violations, and (3) human rights protections on public health promotion. ${ }^{36}$ Given this focus on population-level determinants of vulnerability, Mann argued that 'since society is an essential part of the problem, a societal-level analysis and action will be required', calling for a rights-based AIDS agenda that would frame policies for access to costly medical treatments while maintaining a commitment to infectious disease prevention efforts focused on education, health services, and underlying environments for the public's health. ${ }^{37}$

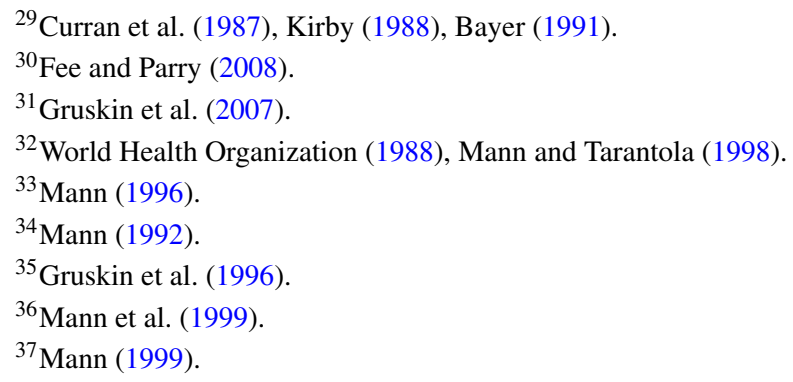




\subsection{Beyond the Individual/Public Health Divide}

Where health-related human rights were largely framed through an individual rightsholder in the latter half of the twentieth century, these individual rights have increasingly proven incommensurate to the globalised public health threats of the new millennium, unable to speak with the collective voice through which infectious disease control efforts must be heard. Infectious disease control efforts represent a global public good, and public goods cannot easily be realised through the individualistic lens of human rights. Reframing the realization of the individual right to health, a collective right to public health has become necessary to give meaning to the health-related human rights of populations, addressing population-level public health interests in infectious disease prevention, detection, and response.

Legal discourses at the intersection of health and human rights have often failed to view public health itself as a human right. Although the tension between individual human rights obligations and governmental public health responsibilities dominated early health and human rights discourses, ${ }^{38}$ an emphasis on this conflict undermines health-related human rights. Whereas many scholars continue to focus on individual negative rights-i.e., those that restrain government action from infringing upon individual liberties - a positive human rights framework acknowledges that governments must act affirmatively to fulfil the economic and social aspects of human rights. ${ }^{39}$ Fulfilling these positive components of health-related human rights requires both an individual right to health and collective rights to public health. ${ }^{40}$

Normative concern for underlying determinants of public health has become a cornerstone of infectious disease control, laying a foundation for the modern health and human rights movement. This movement draws from social medicine-arising out of the industrial revolution in Prussia and France and revitalized during World War II in Great Britain - with social medicine long viewing public health as an interdisciplinary social science that can examine how socioeconomic inequalities shape the health of populations. ${ }^{41}$ Finding that illnesses have multiple population-level causes, social medicine scholars have looked to multisectoral social and political reforms (i.e., underlying determinants of health) rather than medicine as a means of promoting health for the most vulnerable. ${ }^{42}$ In the context of international relations, social medicine defined public health as an inherent matter of government concern, separate and apart from the historical role of international health law in the international projection of economic power and national protection of security interests. Incorporated into international law, such a normative focus on underlying determinants of health was elevated in the aftermath of World War II through the holistic goal proclaimed

\footnotetext{
${ }^{38}$ Childress and Bernheim (2003), King (1999), Gostin and Lazzarini (1997).

${ }^{39}$ Marks (2001).

${ }^{40}$ Meier and Mori (2005).

${ }^{41}$ Rosen (1974).

${ }^{42}$ Ryle (1948), Sand (1934).
} 
by states in the WHO Constitution: 'health is a state of complete physical, mental and social wellbeing and not merely the absence of disease or infirmity'. ${ }^{43}$

Under this rights-based vision of social medicine to address underlying determinants of health, collective rights operate in ways similar to individual rights; however, rather than seeking to empower the individual, collective rights act at a population level to assure public benefits that cannot be fulfilled through individual rights mechanisms. ${ }^{44}$ While Western scholars long presupposed an opposition between individual and collective human rights, ${ }^{45}$ this distinction is inappropriate to infectious disease control in a globalizing world, where the goals of an individual right to health and a collective right to public health complement each other. ${ }^{46}$ Combating the health disparities of a globalized world requires renewed human rights focus - in national policy and global governance-on these collective population-level concerns that underlie the spread of disease.

\section{National Rights-Based Public Health Responses}

In implementing these rights, national disease control policies frequently navigate between state responsibilities to protect the health of the public and obligations to respect the rights of individuals. Balancing tests now detail the rights, conditions, and processes that allow for the permissible derogation of some human rights towards the goal of protecting public health—where rights infringements should be, as reviewed above, based on justifiable limitations, responsive to a pressing social need, in pursuit of a legitimate aim, and proportionate to the health challenge. ${ }^{47}$ State actors are responsible for most human rights infringements, whether permissible or not, and therefore national responses are of utmost importance.

States are in a position in which they have both the duty to respect, protect, and fulfil the right to health and other health-related rights and the power to legitimately restrict rights in order to protect public health. ${ }^{48}$ Most frequently, it is the state's obligation to respect (or refrain from violating) the rights of individuals that is at odds with its responsibility to protect populations-highlighted by rights-infringing efforts to prevent, detect, and respond to infectious disease. This misalignment may create a

\footnotetext{
${ }^{43}$ World Health Assembly, 'Constitution of the World Health Organization' (signed on 22 July 1946, entered into force 7 April 1948) preamble.

${ }^{44}$ Marks (2004).

${ }^{45}$ VanderWal (1990).

${ }^{46}$ Meier (2006).

${ }^{47} \mathrm{UN}$ Commission on Human Rights, The Siracusa Principles on the Limitation and Derogation Provisions in the International Covenant on Civil and Political Rights, UN Doc. E/CN.4/1985/4, 28 September 1984.

${ }^{48}$ UN Committee on Economic, Social and Cultural Rights (CESCR), 'General Comment No. 14: The Right to the Highest Attainable Standard of Health (Art. 12 of the Covenant)' (UN Doc. E/C.12/2000/4, 11 August 2000); UN General Assembly, 'International Covenant on Civil and Political Rights' (Res. 2200A (XXI), 16 December 1966) art. 11.
} 
dual loyalty, where state obligations to respect individual rights may conflict with responsibilities for promoting public health. In order to appropriately balance competing interests, states may look to established international human rights norms and principles for guidance-either prospectively (to guide state public health actions) or retrospectively (to consider missed opportunities to respect rights). Applied in the context of national infectious disease control policies, such norms and principles include those necessary for (1) dignity, (2) non-discrimination, (3) participation, and (4) the right to health.

\subsection{Dignity: Bodily Integrity and Autonomy}

Although never explicitly defined within the human rights corpus, human dignity explicitly underpins all international human rights. The preambular text of the UN Charter states that one of the principal purposes of the UN is 'to reaffirm faith in fundamental human rights, in the dignity and worth of the human person' ${ }^{49}$ Scholars have long debated the precise conceptualisation of the relationship between human dignity and human rights. ${ }^{50}$ Central to bodily integrity and autonomy, dignity is given concrete application in rights-based approaches to prevent, detect, and respond to infectious disease.

Public health practices of isolation and quarantine serve as paradigmatic examples of public health approaches to infectious disease control that may infringe upon individual autonomy via limitations on movement. In the case of isolation, infected individuals are contained to prevent the spread of disease; quarantine is used to confine healthy individuals who have been exposed to disease. The case of 'Typhoid Mary' (who was forcibly isolated after her repeated refusal to cooperate with public health authorities in preventing the spread of her asymptomatic typhoid) exemplifies the need, at times, for state intervention in restricting freedom of movement. ${ }^{51}$ In the government exercise of isolation and quarantine-including the contemporary application of travel restrictions (both within a country and applied to travelers from other countries) in response to COVID-19-the individual right of free movement is in tension with the protection of public health; thus, the rights of the individual are infringed to protect the collective interests of the larger population.

Relatively recent responses to infectious disease outbreaks_-particularly among new or previously unknown infections - have remained grounded in these age-old public health practices. In the early years of the HIV response, the Cuban government was strongly criticised for its use of HIV isolation facilities, known as sanatoriums. ${ }^{52}$ This isolation practice undoubtedly infringed upon the dignity of people living with

\footnotetext{
${ }^{49}$ United Nations, 'Charter of the United Nations' (UN Doc. UNTS XVI, 24 October 1945) preamble.

${ }^{50}$ Donnelly (1982), McDougal et al. (1980).

${ }^{51}$ Marineli et al. (2013).

${ }^{52}$ Bayer and Healton (1989), Hoffman (2004).
} 
HIV/AIDS (PLHA). However, those in the sanatoriums enjoyed access to higher food rations, specialized care for HIV, and relief from employment responsibilities, benefits that were seen as especially advantageous during Cuba's post-Cold War economic crisis, known as the 'special period'. ${ }^{53}$ While the government has stepped away from these rights-infringing practices-employing the sanatoriums now as training centres for HIV diagnosis, education, and care management-Cuba continues to have one of the lowest rates of HIV/AIDS in the region, a public health outcome attributed their early rights-restricting HIV containment practices. ${ }^{54}$ The 2014-16 Ebola Virus Disease epidemic similarly highlighted how well-intentioned public health efforts can infringe individual rights. In Liberia, residents of the West Point neighbourhood were quarantined despite a lack of evidence that the virus was more prevalent there than elsewhere in the country. In the United States, a nurse who tested negative for Ebola was nevertheless confined to isolation, although a court would later overturn this derogation of her rights and restriction on her movement. ${ }^{55}$ Setting a precedent for current lockdowns during the rapidly spreading COVID-19 pandemic, these examples highlight the need for scientific evidence in public health decision making, even in the course of ongoing infectious disease outbreaks; where there is little scientific information related to new and emerging pathogens, research is warranted to understand the threats such pathogens pose to the public's health and the responses that are necessary to prevent disease. These data are critical in balancing risks and benefits to determine the most appropriate and least burdensome policy response, especially when individual rights restrictions include limitations on movement.

Such state restrictions on individual autonomy to protect public health may extend beyond limitations on physical movement to include mandatory treatment. Establishing a precedent for state vaccine mandates that stands to this day, the U.S. Supreme Court's 1905 decision in Jacobson v. Massachusetts ${ }^{56}$ held that the state could enforce compulsory vaccination laws where individual autonomy was deemed subordinate to protecting the health of the population. ${ }^{57}$ Recently, however, there has been an increase in vaccine-preventable diseases in high-income countries. Despite being officially eliminated from the United States in 2000, Measles outbreaks have been reoccurring sporadically throughout the country. ${ }^{58}$ The resurgence of vaccinepreventable diseases in such settings has largely been attributed to vaccine opponents, who refuse vaccinations based upon religious or personal beliefs. ${ }^{59}$ Notwithstanding the proven efficacy of vaccines, the result of this opposition has been to increase

\footnotetext{
${ }^{53}$ Reed (2011).

${ }^{54}$ Joint United Nations Programme on HIV/AIDS (UNAIDS), 'Global Report: UNAIDS Report on the Global AIDS Epidemic' (UNAIDS 2013).

${ }^{55}$ Price (2015).

${ }^{56}$ Jacobson v Massachusetts (1905) 197 US 11.

${ }^{57}$ Mariner et al. (2005).

${ }^{58}$ McCarthy (2015).

${ }^{59}$ Yang et al. (2015).
} 
non-medical vaccine exemptions and, consequently, led to a higher incidence of vaccine-preventable disease in ways that threaten the public's health. ${ }^{60}$

Vaccine refusal highlights issues of individual responsibility. In the case of vaccine opposition (particularly for childhood vaccinations), parents must balance their perceived risk of vaccines against the potential negative outcomes of infection. ${ }^{61}$ For many years, this debate was assuaged by broad acceptance of childhood vaccinations (bolstered by vaccine mandates for school enrollment), which led to substantial decreases in the incidence of vaccine-preventable diseases and the establishment of 'herd immunity' at the population level without the need for vaccine mandates. ${ }^{62}$ In this way, childhood vaccination programmes have become a victim of their own success. The anti-vaccine movement-fuelled in recent years by false concerns about vaccine safety, coupled with religious and philosophical exemptions to school-based vaccine requirements-has provided an opening for the resurgence of vaccine-preventable diseases in places where they were previously rare. ${ }^{63}$ As exemptions to school vaccine mandates have increased, there has been a waning of herd immunity (also known as 'community protection') against vaccine-preventable disease. Community protection relies on such population immunity. It is this herd immunity, not individual disease immunity, that protects a given population. Therefore, those choosing not to vaccinate remain individually vulnerable to infections, which can then be transmitted throughout the community. On the global scale, while vaccines are most frequently viewed as crucial to public health, erroneous perceptions about vaccine safety continue to undermine the potential of vaccines to prevent infectious disease. ${ }^{64}$ This threat from individual refusal to adhere to public health guidelines is similarly seen among those flouting social distancing recommendations to prevent the spread of COVID-19. As a result, public health professionals must reexamine not only individual autonomy, but also individual responsibility towards the community-a concept which varies widely across cultural contexts.

Through the lens of human rights, individual responsibility to the community can be seen as a form of legal duty. Despite cultural variance towards individual and collective duties, the UDHR clarifies that restrictions of individual rights can be undertaken as a basis to respect the 'rights and freedoms of others' in the community. ${ }^{65}$ In the case of exemptions from vaccination, policymakers have sought to make individual exemptions more rare as a basis to protect the public. ${ }^{66}$ Beyond mandates, adherence to the principle of informed consent (including scientifically accurate information on the risks and benefits of vaccination) addresses misinformation and safety concerns while simultaneously supporting autonomy and informed

\footnotetext{
${ }^{60}$ Omer et al. (2006), Omer et al. (2012).

${ }^{61}$ Champion and Skinner (2008).

${ }^{62}$ Roush et al. (2007).

${ }^{63}$ Gust et al. (2008).

${ }^{64}$ Larson et al. (2016).

${ }^{65}$ UN General Assembly, 'Universal Declaration of Human Rights' (Res. 217 A (III), 10 December 1948) art. 29.

${ }^{66}$ Omer (2015).
} 
decision making. Under this model for balancing individual rights and public health, receiving a vaccine exemption would be possible, but perhaps more difficult, in an effort to push individuals towards vaccination. This model could increase levels of individual vaccination and herd immunity - achieving a public health goal in balance with standards of human dignity.

\subsection{Non-discrimination and Stigma}

With this imperative for dignity through human rights requiring an emphasis on nondiscrimination and equality, the attention to vulnerable populations in both human rights treaties and human rights institutions was born of the Holocaust experience of World War II, wherein the Nazi crimes against humanity implicated the discriminatory targeting of specific populations. Today, each core human rights treaty includes a non-discrimination clause that prohibits discrimination on the basis of, at a minimum, race, sex, language, and religion. At times, additional language has been used to expand beyond these categories, including prohibitions on discrimination on the basis of disability and health status. Although some of these characteristics were once viewed as both biologically-dictated and immutable, evolving notions of social constructions in the context of race and gender have allowed for flexibility and inclusiveness, rather than a rigid dogmatism linked to specific terms, in a more expansive view of human rights.

Human rights protections against stigma and discrimination are now seen as 'inextricably linked' to the realisation of public health goals. The emergence of HIV/AIDS exacerbated the social stigma, homophobia, and racism targeted against injection drug users, men who have sex with men (MSM), and racial minority groups. Furthering this discrimination through public health policy, the U.S. Centers for Disease Control and Prevention's '4H club' identified homosexuals, heroin users, haemophiliacs and Haitians as specific at-risk groups. This well-intentioned and catchy phrase led to devastating results, with vulnerable groups experiencing housing and employment discrimination, and the impoverished island of Haiti experiencing an $80 \%$ decrease in tourism. ${ }^{67}$ Such stigma towards risk groups, rather than behaviours, is currently unfolding in the COVID-19 response, where individuals of Asian descent have been stigmatised by the label of the 'Chinese virus', facing discrimination, violence, and health care denial based upon racist demagoguery from nationalist politicians.

Through his work to advance human rights in WHO, Jonathan Mann sought to identify the linkages between human rights frameworks and the stigma and discrimination faced by vulnerable populations. Mann's vision of discrimination as harmful to public health and his understanding that individual behaviour change was key to disease prevention was prescient, giving rise to a health and human rights movement that would seek to end discrimination in public health practice. This discrimination,

${ }^{67}$ PBS Frontline (2006). 
embodied by the longstanding US travel ban against HIV-positive individuals, was finally lifted only in 2010. ${ }^{68}$ Rather than discussing risk groups or identity groups, policymakers now talk about risk behaviours underlying infection and key groups.

Where human behaviours and discriminatory attitudes may be exceedingly difficult to change, laws and policies provide a rights-based foundation upon which social norms may draw reference. The incorporation of human rights principles into legal and policy reforms has shown promise in reducing HIV/AIDS-related stigma and discrimination. ${ }^{69}$ Legal protections for those infected or in groups at high risk of HIV infection (including MSM, injection drug users, and commercial sex workers) may prevent and mediate individual and institutionalised forms of stigma and discrimination. ${ }^{70}$ These protections are inherently linked to the human rights principle of non-discrimination; related reductions in stigma surrounding risk behaviours, mother to child transmission of HIV, and HIV testing and treatment remain vital to both discrimination against vulnerable populations and reduction of disease transmission. ${ }^{71}$ In the context of COVID-19, stigma and discrimination act as kindling for the spread of the infection among detained populations and homeless people who are vulnerable because of both their housing and their membership in socially stigmatized groups.

\subsection{Participation}

The participation of civil society and affected populations in holding duty bearers accountable for implementing these human rights obligations is a critical principle for the advancement of human rights. Such participation is necessary, in large part, because states are both duty-bearers and the most frequent violators of human rights. ${ }^{72}$ This engagement in government processes is extremely important; in the case of health, participation in political debates may entail opportunities for direct action where community members are affected by health care goods, facilities, and services. ${ }^{73}$ As such, participation plays a vitally important role in infectious disease control. In the South African case of the Ministry of Health vs. Treatment Action Campaign (TAC), the South African Constitutional Court found that the state was responsible under the right to health for the provision of antiretroviral drugs to pregnant persons for the prevention of mother to child transmission of HIV. ${ }^{74}$ TAC played a critical participatory role in both bringing the legal case and advocating publicly for the availability of antiretrovirals for all HIV-positive South Africans. Civil society

\footnotetext{
${ }^{68}$ Preston (2009).

${ }^{69}$ Mahajan et al. (2008).

${ }^{70}$ Rhodes et al. (2005).

${ }^{71}$ Mahajan et al. (2008).

${ }^{72}$ Potts (2008).

${ }^{73}$ Meier et al. (2012).

${ }^{74}$ Giliomee and Mbenga (2007).
} 
groups, including non-governmental organizations, can also play an important formal role within international human rights mechanisms through the provision of shadow reports to the UN bodies responsible for monitoring human rights treaty compliance. While the UN Committee on Economic, Social and Cultural Rights is the primary treaty body responsible for monitoring the right to health, numerous other human rights bodies examine health-related human rights, incorporating participation from civil society actors in their assessments of national human rights implementation efforts. $^{75}$

Community members can additionally be health agents locally, acting as health resources, improving governmental capacity for health, and supporting primary health care. ${ }^{76}$ However, doctors, nurses, and public health professionals often face dual loyalty when, as in many countries, they work within national health systems. ${ }^{77}$ Health professionals employed by such systems are state actors and have professional obligations to their employers, but at the same time, they have ethical obligations to those affected by health systems. While setting health policy, health professionals may also be directly providing health services at the community level.

Advancing their work as health agents, some community members may pursue formal medical and public health training, engaging in the health sector by becoming health practitioners while simultaneously representing the interests of their communities. Innovative models of medical and public education such as that of the Latin American School of Medicine (ELAM), which has the right to health mainstreamed throughout its curriculum, facilitate the training of disadvantaged groups who are most likely to return to serve their home communities. ${ }^{78}$ The purposeful recruitment of marginalised populations into the health professions has shown demonstrated benefits for participation in the health system. ${ }^{79}$

It is not only those with clinical training who can participate in community level health delivery. The Chinese 'Barefoot Doctors' programme of the late 1960s established a framework for community based primary health care. Since 1970, Where There Is No Doctor has become one of the most widely used health care manuals, and both WHO and UNICEF use the text in their field offices, equipping readers with vital health information for personal and community based decision making. ${ }^{80}$ The text has been credited with making basic health information, including information

\footnotetext{
${ }^{75}$ See, for example, United Nations (UN), 'NGO Participation at CEDAW sessions' (UN Women) http://www.un.org/womenwatch/daw/ngo/cedawngo.

${ }^{76}$ International Conference on Primary Health Care, 'Declaration of Alma-Ata' (6-12 September 1978).

${ }^{77}$ Physicians for Human Rights \& School of Public Health and Primary Health Care, University of Cape Town, Health Sciences Faculty, 'Dual Loyalty \& Human Rights in Health Professional Practice; Proposed Guidelines \& Institutional Mechanisms' (2002) https://s3.amazonaws.com/PHR_ Reports/dualloyalties-2002-report.pdf.

${ }^{78}$ Primer Hospital Popular Garifuna, 'Our History' (Primer Hospital Popular Garifuna) http:// primerhospitalgarifuna.blogspot.com/p/ingles.html.

${ }^{79}$ Institute of Medicine (2003), Saha et al. (1999).

${ }^{80}$ Werner et al. (1992).
} 
on hygiene and infectious diseases, globally accessible. ${ }^{81}$ In accordance with community level health delivery, Community Health Workers (CHWs) play an extremely important role in the delivery of services ${ }^{82}$ and the response to infectious disease. ${ }^{83}$ Partners in Health (PIH), philosophically grounded in liberation theology, was an early adopter of community participation in infectious disease prevention and control. PIH successfully promoted the participation of affected communities in the early use of antiretroviral therapy in Haiti, resulting in improved compliance with what were then more rigorous medicine regimens. ${ }^{84}$ Their success in this approach, coupled with rights-based advocacy efforts, has resulted in a sea change in thinking about the feasibility of antiretroviral therapy among populations in low-resource settings. The COVID-19 response highlights the continuing importance of participation, where adherence to social distancing, self-isolation, and shelter in place policies are designed to "flatten the curve"; yet, without widespread community participation, such critical policies are ineffective, if not meaningless.

\subsection{The Right to Health}

These rights-based approaches to infectious disease have been structured by the right to health, framed by attributes that examine the availability, accessibility, acceptability and quality (AAAQ) of health goods, facilities, and services. The UN Committee on Economic, Social and Cultural Rights outlined these four interconnected and essential attributes of the right to health, ${ }^{85}$ which have specific application to infectious disease efforts, as highlighted by infectious disease prevention and response during the 2014-2016 Ebola Virus Disease epidemic and the ongoing COVID-19 pandemic.

Under this AAAQ framework, availability pertains to the quantity of health goods, facilities, and services available within a given country context; the concept includes essential medicines as defined by WHO and the underlying determinants of health like safe potable drinking water. ${ }^{86}$ When Ebola emerged in 2014 in West Africa, the three affected countries (Guinea, Liberia, and Sierra Leone) were particularly vulnerable. Colonized by three different colonial powers, the countries share a history of military coups, dictatorship, civil war, and strife, which have resulted in the destruction of virtually all health care infrastructures, widespread poverty, and a lack of trust in

\footnotetext{
${ }^{81}$ Godlee et al. (2004).

${ }^{82}$ Figueroa-Downing et al. (2016).

${ }^{83}$ De Oliveria Chiang et al. (2015).

${ }^{84}$ Koenig et al. (2004).

${ }^{85}$ UN Committee on Economic, Social and Cultural Rights (CESCR), 'General Comment No. 14: The Right to the Highest Attainable Standard of Health (Art. 12 of the Covenant)' (UN Doc. E/C.12/2000/4, 11 August 2000).

${ }^{86}$ UN Committee on Economic, Social and Cultural Rights (CESCR), 'General Comment No. 14: The Right to the Highest Attainable Standard of Health (Art. 12 of the Covenant)' (UN Doc. E/C.12/2000/4, 11 August 2000).
} 
public institutions. ${ }^{87}$ Ebola capitalised upon these institutional weaknesses to create a perfect storm of public health, humanitarian, and human rights crises. The global community belatedly rushed to build Ebola Treatment Units (ETUs), as nations are seeking today to build hospitals to take in COVID-19 patients, but could offer little in terms of treatment. As seen in the early COVID-19 response, the shortage of surge capacity for face masks, ventilators, Personal Protective Equipment (PPE), and other essential medical equipment underscores that the global community has not yet learned the importance of public health preparedness. Key lessons from these public health emergencies relative to availability include the importance of investment in trained health professionals, facilities, and surveillance systems. ${ }^{88}$

Accessibility of health care and health care systems is operationalised in four ways. Facilities must be geographically and physically accessible, services must be affordable or economically accessible to users, care should be provided in a nondiscriminatory manner (with vulnerable and marginalised populations prioritised), and both users and health personnel should be able to confidentially seek and receive health information. ${ }^{89}$ Where health care facilities and personnel were extremely limited in the West African context at the start of the Ebola epidemic, infected people likely delayed seeking care due to poverty, and, later, ETUs were viewed as 'death centres'. Beyond care, it has been necessary in both the Ebola and COVID-19 response to have access to water, sanitation, and hygiene. Even where physically accessible, access to health information is critical to disease control, as seen where the availability of chlorine water buckets for handwashing was useless in the Ebola response without accompanying messaging about why and how to use them. ${ }^{90}$

Examining the acceptability of behaviour change relating to cultural practicesfrom mundane handshakes to sacred burials ${ }^{91}$ - these practices were socially important and changing them was crucial to preventing Ebola transmission, as they will be necessary to understand and change the course of transmission during the COVID-19 pandemic. The concept of acceptability encompasses the oft-debated human rights notion of cultural relativism, requiring that health goods, facilities, and services are culturally appropriate. ${ }^{92}$ In the case of Ebola in West Africa, nuanced approaches to behaviour change were necessary to ensure the prevention of disease, including engagement with religious and community leaders in the development of culturally

\footnotetext{
${ }^{87}$ Dabney P. Evans \& Carlos del Rio, 'Ebola Virus Disease: An Evolving Epidemic.' (Coursera) https://www.coursera.org/learn/ebola-virus.

${ }^{88}$ Crawford et al. (2016).

${ }^{89}$ UN Committee on Economic, Social and Cultural Rights (CESCR), 'General Comment No. 14: The Right to the Highest Attainable Standard of Health (Art. 12 of the Covenant)' (UN Doc. E/C.12/2000/4, 11 August 2000).

${ }^{90}$ Dabney P. Evans \& Carlos del Rio, 'Ebola Virus Disease: An Evolving Epidemic.' (Coursera) https://www.coursera.org/learn/ebola-virus.

${ }^{91}$ del Rio et al. (2014).

${ }^{92}$ UN Committee on Economic, Social and Cultural Rights (CESCR), 'General Comment No. 14: The Right to the Highest Attainable Standard of Health (Art. 12 of the Covenant)' (UN Doc. E/C.12/2000/4, 11 August 2000).
} 
acceptable alternatives to traditional practices. ${ }^{93}$ The concept of acceptability is also closely aligned with traditional discussions of medical ethics. ${ }^{94}$ In accordance with such ethical principles, the lack of a cure and limited knowledge about effective Ebola treatment required that those treating cases in well-resourced settings rapidly share information with those in West Africa. ${ }^{95}$

Quality requires that health facilities, goods, and services are scientifically and medically appropriate. ${ }^{96}$ Assuring such quality pursuant to the right to health requires, inter alia, unexpired drugs and equipment and appropriate training for health personnel. In the case of both Ebola and COVID-19, many early casualties of the disease were care givers, including health personnel. With respect to protecting care givers, the importance of correctly donning and doffing PPE is critical in slowing the spread of disease among those in direct contact with infected individuals. The practice was even successfully adopted by a nursing student who used garbage bags to protect herself from Ebola infection while caring for sick family members; in the absence of equipment in the COVID-19 response, seamstresses everywhere have coalesced to sew needed face masks for medical personnel. ${ }^{97}$

This examination of efforts to address Ebola and COVID-19 through the AAAQ lens provides useful insights into missed opportunities for the application of the right to health to infectious disease control policy and future directions for public health responses.

National governments are only beginning to apply health-related human rights in addressing infectious disease-including the right to health, health-related human rights, and cross-cutting rights-based principles of dignity, non-discrimination, and participation-but despite the control of some infectious diseases, there is more that must be done. ${ }^{98}$ Tuberculosis (TB) kills millions each year, ${ }^{99}$ yet lack of access to treatment for key populations remains a challenge, worsened for those marginalised by HIV co-infection or Multi Drug Resistant TB (MDR-TB). HIV/AIDS, now in its fourth decade as a global pandemic, continues to disproportionately affect impoverished populations, racial and ethnic minorities, the incarcerated, and sexual minorities. Inadequate attention to vector-borne diseases like Zika have resulted in devastating consequences for marginalized populations, including among poor

\footnotetext{
${ }^{93}$ Dabney P. Evans \& Carlos del Rio, 'Ebola Virus Disease: An Evolving Epidemic.' (Coursera) https://www.coursera.org/learn/ebola-virus.

${ }^{94}$ UN Committee on Economic, Social and Cultural Rights (CESCR), 'General Comment No. 14: The Right to the Highest Attainable Standard of Health (Art. 12 of the Covenant)' (UN Doc. E/C.12/2000/4, 11 August 2000).

${ }^{95}$ Lyon et al. (2014); Dabney P. Evans \& Carlos del Rio, 'Ebola Virus Disease: An Evolving Epidemic.' (Coursera) https://www.coursera.org/learn/ebola-virus.

${ }^{96}$ UN Committee on Economic, Social and Cultural Rights (CESCR), 'General Comment No. 14: The Right to the Highest Attainable Standard of Health (Art. 12 of the Covenant)' (UN Doc. E/C.12/2000/4, 11 August 2000).

${ }^{97}$ Dabney P. Evans \& Carlos del Rio, 'Ebola Virus Disease: An Evolving Epidemic.' (Coursera) https://www.coursera.org/learn/ebola-virus.

${ }^{98}$ Barrett et al. (1998).

${ }^{99}$ World Health Organization (2016).
} 
Afro-Brazilian populations. COVID-19 has already descended the social gradient to become a disease of the poor and marginalised, exposing the continuing weaknesses of national efforts to see individual rights as inextricably linked with public health efforts. Despite the challenges posed by existing and emerging infectious diseases, human rights-based approaches offer a framework for advancing national disease control efforts. However, the continuing limitations of these national policies highlight the need for rights-based global health governance.

\section{Development of Rights-Based Global Health Governance for Infectious Disease Prevention, Detection, and Response}

Globalisation has channelled the spread of disease, connected societies in shared vulnerability, and highlighted the risks posed by inadequate national policies. ${ }^{100}$ Yet if globalisation has presented challenges to infectious disease control, globalised institutions offer the promise of bridging national boundaries to alleviate these common threats through global health governance for infectious disease prevention, detection, and response. Global collective action through international law is essential to develop the rights-based governance structures for realizing global solidarity in dealing with global infectious disease threats that are outside the control of individual states. ${ }^{101}$

\subsection{Infectious Disease Control Gives Birth to Global Health Governance}

Collective international governance for infectious disease control has evolved over the past two centuries. Propelled by the steam of industrialisation, migration from rural to urban areas, and cross-border travel and trade challenged nation-states in the nineteenth century to cooperate in the prevention, detection, and control of infectious diseases. As cholera spread throughout Europe in the early-to-mid nineteenth century, individual states, still unaware of modern principles of epidemiology or microbiology, responded by imposing burdensome restrictions on merchants and travellers, including the quarantine of travellers, the disabling of ships, and the destruction of cargo.

Given the constraints of these national restrictions on international commerce, ${ }^{102}$ international health law would seek to coordinate national public health responses

\footnotetext{
${ }^{100}$ Taylor (2004).

${ }^{101}$ Slaughter (1997).

${ }^{102}$ Howard-Jones (1975).
} 
to protect international economic and security interests against infectious disease threats. In 1851, twelve nations met for the first of fourteen International Sanitary Conferences, seeking to stem the spread of infectious disease across Europe without unduly hindering commerce. ${ }^{103}$ While a lack of scientific understanding and international consensus stymied international agreement during early conferences, ${ }^{104}$ evolving understanding of infectious disease epidemiology finally led to the development in 1892 of a binding agreement: the International Sanitary Convention (ISC). ${ }^{105}$ Driven by national security and economic interests rather than a desire to protect the public's health — as either a public good or a human right ${ }^{106}$ — states agreed under the ISC to notify each other urgently of outbreaks of specific diseases within their territories, and that the only goods subject to any restrictions would be clothes, bed linen, and rags. There would be no land quarantine, but travellers with cholera or cholera-like symptoms could be detained in isolation. ${ }^{107}$ Over the next thirty years, nations adopted additional conventions under the ISC, and by 1926, international law covered three main diseases: cholera, plague, and yellow fever. ${ }^{108}$ When WHO was established in 1948 to facilitate post-war international health cooperation, oversight and management of the ISC was incorporated into the Organisation's mandate. ${ }^{109}$

Under the WHO Constitution, the World Health Assembly (WHA), the annual meeting of WHO member states, would have authority to adopt sanitary, quarantine, and other regulations designed to prevent the international spread of diseases. ${ }^{110}$ These international regulations would be automatically binding on all WHO member states unless they expressly opt-out within a specified period. ${ }^{111}$ In 1951 , the WHA renamed the ISC the 'International Sanitary Regulations' and expanded their scope to include smallpox, typhus, and relapsing fever. The WHA removed the latter two diseases in 1969 and renamed these regulations the International Health Regulations (IHR). In 1981, smallpox was also removed following its global eradication, returning the IHR to the initial three diseases that sparked international health diplomacy: cholera, plague, and yellow fever. Yet, as the world faced a continuous stream of emerging and re-emerging diseases, the principal international law for preventing, detecting, and responding to infectious disease outbreaks was increasingly seen as inadequate.

\footnotetext{
${ }^{103}$ Ibid., 12. The participating nations in the first International Sanitary Conference were France, Austria, the Two Sicilies, Spain, the Papal States, Great Britain, Greece, Portugal, Russia, Sardinia, Tuscany, and Turkey.

${ }^{104}$ Ibid., 17-57, 65.

${ }^{105}$ Ibid., 65.

${ }^{106}$ Gostin and Katz (2016).

${ }^{107}$ Ibid., 70.

${ }^{108}$ Ibid.

${ }^{109}$ World Health Organization (1958).

${ }^{110}$ World Health Assembly, 'Constitution of the World Health Organization' (signed on 22 July 1946, entered into force 7 April 1948) art. 21(a).

${ }^{111}$ Ibid., art. 22.
} 
In addition to its under-inclusivity in addressing the expanding range of infectious disease threats, the IHR also failed to incorporate individual human rights protections. Under the 1969 IHR, states were expressly prohibited from requiring vaccinations against plague upon entry and subjecting individuals to rectal swabbing to test for cholera; however, neither prohibition of these bodily intrusions was couched as a protection of human rights. This neglect of human rights is surprising given the parallel development of UN human rights treaties during this period and the explicit inclusion of the right to health in the 1948 WHO Constitution, placing human rights at the centre of international health law. ${ }^{112}$ Despite calls for the revision of the IHR to address these perceived weaknesses, it took the emergence of a previously unknown infectious disease to prompt international action.

Severe acute respiratory syndrome (SARS) emerged in Guangdong, China in late 2002. Concerned that international travel and trade restrictions would be imposed to control this infectious disease, thereby hampering national economic growth, China did not inform the international community of this emerging disease-as SARS was not one of the three diseases that states were specifically obligated to report to WHO under the IHR. ${ }^{113}$ In February, 2003, SARS began to spread internationally, ${ }^{114}$ prompting the Chinese government for the first time to report cases to WHO and allow previously-obstructed WHO officials and epidemiologists into the country. China's delays in accurately reporting the SARS outbreak-compounded by prohibitions on local Chinese government officials from disclosing public health outbreaks, deemed state secrets, until announced by the Ministry of Health in Beijing ${ }^{115}$ _ drew widespread international condemnation, including from the WHO Director-General. ${ }^{116}$ Only once the international community was formally aware of the outbreak did Chinese officials begin to impose strict cordons sanitaires and quarantines, swiftly closing universities, villages, and apartment buildings and imposing mass quarantines affecting more than 30,000 people in Beijing alone. ${ }^{117}$ China's judiciary thereafter issued an edict that existing laws criminalising the intentional spread of disease applied to SARS, carrying a punishment from 10 years imprisonment to execution. ${ }^{118}$ Yet these public health measures were criticised as being applied arbitrarily and in a discriminatory manner ${ }^{119}$ and thus inconsistent with the legitimate public health use of quarantines or isolation measures. While these state

\footnotetext{
${ }^{112}$ Pannenborg (1979).

${ }^{113}$ United States Congressional-Executive Commission on China (CECC) (2003).

${ }^{114}$ Huang (2004).

${ }^{115}$ Gill (2003).

${ }^{116}$ Fleck (2003).

${ }^{117}$ Huang (2004), Centers for Disease Control and Prevention (CDC) (2003).

${ }^{118}$ Eckholm (2003).

${ }^{119}$ 'US Criticised China over Death Penalty for SARS Quarantine Violations' (Agence France-Presse 16 May 2003) http://global.factiva.com/redir/default.aspx?P=sa\&an= afpr000020030516dz5g00mri\&cat=a\&ep=ASE.
} 
measures were consistent with international health law, they risked violating international human rights law, including protections of the right to life, right to health, freedom of movement, and freedom of speech. ${ }^{120}$

With SARS highlighting the weaknesses of international law for infectious disease control, the international community would commit not only to update the breadth, scope, and notification obligations under the IHR, but also to address the absence of human rights protections under international health law.

\subsection{The Revised International Health Regulations (2005)}

On 23 May 2005, the 58th WHA adopted the revised IHR, marking a significant shift in the relationship between human rights and the prevention, detection, and response to infectious disease under international law. Adopted under Articles 21 and 22 of the WHO Constitution, the IHR became automatically binding on all WHO member states and entered into force in July 2007. The purpose of the revised IHR is to prevent, protect against, control, and respond to the international spread of infectious disease through public health measures that avoid unnecessary interference with international traffic and trade. ${ }^{121}$ Much like the International Sanitary Conventions of the nineteenth century, merchants and travellers are the primary focus of these provisions, which aim to respond to any Public Health Emergency of International Concern (PHEIC), including the introduction and spread of a disease from one country into another. Implemented by national governments, state sovereignty continues to be a central tenet of the IHR, reflected in principles that provide states the sovereign responsibility to develop health legislation to address a specific public health risk. However, this domestic legislation 'should uphold the purpose' of the IHR, ${ }^{122}$ reinforcing international commitments under both international health law and international human rights law.

\subsubsection{Domestic Implementation of Human Rights Through the IHR}

Human rights are at the forefront of principles underpinning the IHR, requiring that the domestic implementation of the IHR shall be guided by the UN Charter and the WHO Constitution and 'shall be with the full respect for the dignity, human rights and fundamental freedoms of persons' ${ }^{123}$ Reflecting this new rights-based focus, the IHR's general health measures (i.e., those not specific to travellers) reinforce the centrality of human rights to the global governance of infectious disease. As a cornerstone principle of human rights, any health measure taken by a country in

\footnotetext{
${ }^{120}$ Fidler (2003).

${ }^{121}$ World Health Organization, 'International Health Regulations (2005)' (2008) art. 2.

${ }^{122}$ Ibid., art. 4.

${ }^{123}$ Ibid., art. 3(1).
} 
accordance with the IHR must be applied in a transparent and non-discriminatory manner. ${ }^{124}$ The IHR do not preclude countries from implementing health measures within their territory in response to a PHEIC; however, such measures must be in accordance with both national and international law. Thus, national measures must achieve at least the same level of health protection as WHO recommendations and must not be more restrictive of international traffic, or more invasive or intrusive to individuals, than reasonably available alternatives. ${ }^{125}$

Crucially, the IHR provide that an imminent public health risk does not displace a state's non-derogable obligations under human rights law. These include respecting, protecting, and fulfilling the right to life, freedom from torture, cruel, inhuman, or degrading treatment, and freedom from non-consensual medical experimentation. In addition to limits on the domestic health measures that a WHO member state may take, the IHR additionally limit the nature of health measures governments may take with respect to travellers, requiring that states treat travellers with respect for their dignity, human rights, and fundamental freedoms as well as minimise any discomfort or distress arising from the health measures taken. ${ }^{126}$ Protecting the rights of travellers in the implementation of health measures, the IHR require that states consider the gender, sociocultural, ethnic, or religious concerns of travellers. ${ }^{127}$

Yet states have not always complied with these human rights principles in the implementation of the IHR. During the 2014-2016 Ebola epidemic, Liberia, Sierra Leone, and Guinea implemented a triangular, regional cordon sanitaire where the three national borders meet. ${ }^{128}$ This cross-border area already had a long history of restrictive health responses, having faced prior colonial campaigns of cordoning entire villages affected by infectious diseases. ${ }^{129}$ Responding to these Ebola restrictions, the WHO spokesperson stated that while WHO would not be against the use of a cordon sanitaire, 'human rights have to be respected' ${ }^{130}$ The effective implementation of a cordon sanitaire invariably impacts the right to movement, yet during an extraordinary public health event, it may be the least restrictive option based upon scientific evidence and principles. However, if not implemented in accordance with human rights, cordons sanitaires may additionally lead to the deprivation of other health-related human rights, including the right to health, the right to food, the right to water, and the non-derogable right to life. ${ }^{131}$ Compounding these rights violations, the Liberian government additionally imposed an expansive quarantine over the West Point area of Monrovia in August 2014, contradicting public health recommendations and forcing at least 75,000 people to remain in overcrowded and

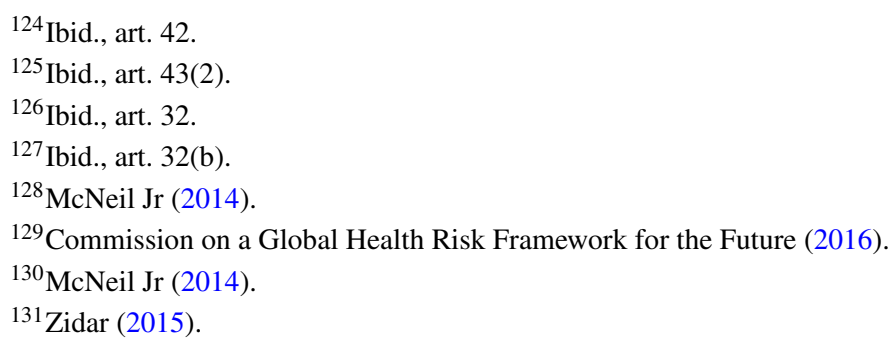


unsanitary conditions. ${ }^{132}$ After ten days of restrictions on access to food, water, and other determinants of health-resulting in deadly clashes between residents and the military - the government was forced to remove the quarantine order. ${ }^{133}$ Tested by the 2014-2016 Ebola epidemic, the public health and human rights safeguards contained in the IHR remained insufficient to prevent the use of unnecessary and IHRnon-compliant domestic health measures, setting a precedent that would be vastly expanded amidst the rights violations accompanying cordons sanitaires employed by China in the early COVID-19 response. ${ }^{134}$

\subsubsection{Human Rights Protections for Travellers}

The IHR additionally establish normative standards for the health measures states may take to mitigate the international spread of disease, including express consideration of the human rights of travellers to protect individual dignity. Upon arrival or departure, states may gather information on a traveller's travel history or destination for the purpose of contact tracing (to assess possible exposure to an infectious disease) or require a non-invasive medical examination (provided that it is the least intrusive examination required to achieve the relevant public health aim). ${ }^{135}$ Such non-invasive medical examinations can include visual examination of the ear, nose, and mouth, temperature assessment using an ear, mouth, or skin thermometer or thermal imaging, measurement of blood pressure, or the external collection of urine, faeces, or saliva samples. ${ }^{136}$ If the initial examination shows a public health risk exists, countries may, on a case-by-case basis, apply additional health measures on the affected or suspected traveller; however, such measures must be the least intrusive and least invasive means to prevent the international spread of disease, must be consistent with the IHR, and as a result, must avoid unnecessary infringements of human rights. ${ }^{137}$ Respecting human dignity and bodily integrity, no medical examination (invasive or non-invasive), vaccination, prophylaxis, or other health measure can be performed on travellers without their prior express informed consent or, for individuals without capacity to give fully informed consent, parental or guardian consent. ${ }^{138}$ However, if a traveller fails to consent to invasive medical examinations or provide information necessary for contact tracing, the country may, where there is an imminent public health risk, compel or advise the traveller to undergo the least invasive and intrusive medical examination necessary, vaccination or prophylaxis, or other health measures such as quarantine or isolation. ${ }^{139}$ For travellers that are

\footnotetext{
${ }^{132}$ Onishi (2014).

${ }^{133}$ Amon (2014a).

${ }^{134}$ Habibi et al. (2020).

${ }^{135}$ World Health Organization, 'International Health Regulations (2005)' (2008) art. 23.1(a).

${ }^{136}$ Ibid., art. 1.

${ }^{137}$ Ibid., art. 23(2).

${ }^{138}$ Ibid., art. 23(3).

${ }^{139}$ Ibid., art. 31(2).
} 
quarantined, isolated, or subjected to medical examination or other public health procedures, countries must provide (in accordance with human rights obligations) adequate food and water, accommodation, and clothing, protection of possessions, medical treatment, and means of communication in a language the traveller can understand. ${ }^{140}$

Facilitating accountability for these standards through WHO monitoring, a state must notify WHO if it implements any additional health measure that significantly interferes with international travel, such as refusing entry or prohibiting departure of travellers for more than 24 hours, providing WHO with its public health rationale and scientific basis for these travel restrictions. ${ }^{141}$ In response, WHO can request that the state reconsider its measures; however, there is no formal IHR enforcement mechanism or process if human rights are being violated or unduly burdened. Further limiting accountability through WHO, this international monitoring mechanism is not activated if state measures are domestically focused and do not have a significant impact on international travel. Where countries engage in exclusively domestic health measures that may violate human rights, the IHR remain silent, with states bound only by independent international human rights obligations and any normative influence found through the 'temporary recommendations' process during a PHEIC.

\subsubsection{PHEICs and Temporary Recommendations}

The revised IHR take an 'all-hazards' approach to PHEICs. No longer limited to specific infectious diseases, the obligations under the IHR apply to 'any illness or medical condition, irrespective of origin or source, that presents or could present significant harm to humans' ${ }^{142}$ Requiring states to notify WHO of any and all events that may potentially constitute a PHEIC, ${ }^{143}$ the revised IHR were also updated to allow WHO to receive information about possible events from a broad range of sources beyond member states, such as through the media, civil society, and countries that are not WHO member states. ${ }^{144}$ This new provision filled a critical gap in previous versions of the IHR in cases where a government, as seen during SARS, fails to comply with its notification obligation. ${ }^{145}$ Despite addressing this gap, the implementation of this provision has been negated in practice, with scientists and civil society denied the use of this right to share information, and the media, as seen in the COVID-19 outbreak, facing imprisonment for reporting necessary public health information. ${ }^{146}$

\footnotetext{
${ }^{140}$ Ibid., art. 33(c).

${ }^{141}$ Ibid., art. 43(3).

${ }^{142}$ Ibid., art. 1.

${ }^{143}$ Ibid., art. 6.

${ }^{144}$ Ibid., art. 9.

${ }^{145}$ Baker and Fidler (2006).

${ }^{146}$ Davies (2017).
} 
Upon notification, the WHO Director-General, advised by an Expert Committee, independently declares whether such an event constitutes a PHEIC, ${ }^{147}$ and may then issue temporary recommendations to WHO member states on the measures they should, or should not, implement to address the public health threat. ${ }^{148}$ These recommended measures may include how persons and goods are to be treated by countries, including recommendations either for or against restrictions at points of entry (land borders, airports, and ports), the use of quarantine or isolation, the requirements of medical examinations, treatments, or vaccinations, contact tracing, access to medical records, or travel and trade restrictions.

These WHO recommendations under the IHR are intended to guide IHR implementation with full respect for the dignity, human rights, and fundamental freedom of persons. The protection of human rights is enshrined in the factors that the WHO Director-General may consider in issuing, modifying, or terminating recommendations, which include health measures that (on the basis of a risk assessment) are not more intrusive to persons than reasonably available alternatives. ${ }^{149}$ While these temporary WHO recommendations are non-enforceable under international law, they are intended to carry the normative weight of WHO authority in global health governance, prescribe best practices in public health, and provide an informal basis for accountability where countries do not follow them.

Yet, in spite of the authority of these WHO recommendations, countries around the world have implemented health measures contrary to WHO recommendations during the H1N1 influenza PHEIC, the 2014-2016 Ebola PHEIC, and the ongoing COVID-19 PHEIC. ${ }^{150}$ For example, WHO's temporary recommendations during the Ebola PHEIC advised that there should be no restrictions on international travel or trade_-recommending against the banning of flights from affected countries or other border restrictions - as such travel restrictions infringe upon the freedom of movement and correspondingly limit life-saving humanitarian provisions and critically needed medical professionals from reaching the affected countries. Despite this, nearly 30 countries had imposed travel bans by November 2014, including Australia and Canada, both high-income countries with developed public health systems. ${ }^{151}$ To assure greater compliance with future recommendations, WHO Director-General Margaret Chan called in October 2015 for accountability mechanisms under the IHR, including sanctions for countries that restrict international travel and trade. ${ }^{152}$ This was echoed in the report of the Ebola Interim Assessment Panel, tasked with reviewing the IHR and WHO in response to the Ebola epidemic. ${ }^{153}$ However, other independent reviews such as the Harvard-LSHTM Independent Panel on the Global Response to Ebola concluded that economic incentives and the use of existing WHO

\footnotetext{
${ }^{147}$ World Health Organization, 'International Health Regulations (2005)' (2008) art. 12.

${ }^{148}$ Ibid., art. 15.

${ }^{149}$ Ibid., art. 7(d).

${ }^{150}$ World Health Organization $(2009,2014)$.

${ }^{151}$ Taylor (2014).

${ }^{152}$ De Bode (2015).

${ }^{153}$ Ebola Interim Assessment Panel (2015).
} 
powers to publicly examine countries' rationales for their health measures may be more effective. ${ }^{154}$ Notwithstanding these universal recommendations to curtail unnecessary travel restrictions, nations have largely disregarded these WHO recommendations again in the COVID-19 response, with nationalist governments rapidly enacting emergency travel bans that have divided the world and threatened global governance while providing only marginal health benefits. ${ }^{155}$

The implementation of the IHR is intended to be carried out with full respect for human rights and fundamental freedoms, and the laws, structures, and procedures that countries employ to meet their IHR obligations must be compatible with international human rights obligations. By extension, satisfactory implementation of the IHR domestically should ensure that human rights are respected, protected, and fulfilled - not only for travellers but for all residents. Where the Ebola epidemic and COVID-19 pandemic have highlighted the practical limitations of the IHR temporary recommendations, there remain accountability challenges in assuring rights-based approaches to PHEICs.

\subsection{Implementation of the IHR and the Global Health Security Agenda}

The limitations of IHR implementation over the past decade have forced countries to develop new forms of global governance for infectious disease control. While states are required to report to WHO on their progress in achieving a set of core capacities deemed necessary for fulfilment of their IHR obligations to detect, report, and respond to public health threats, ${ }^{156}$ only $22 \%$ of countries reported by their 2012 deadline that they had met these capacity requirements. ${ }^{157}$ In an effort to independently assess state progress in implementing the IHR, WHO in 2016 formally adopted a joint external evaluation (JEE) tool that established an independent expert review process to assess national progress against IHR core capacities, find gaps in implementation, and identify best practices. ${ }^{158}$ Given the slow and inconsistent implementation of the IHR, states additionally looked to develop new institutions of global governance to prevent, detect, and respond to public health emergencies. A partnership of forty countries and international organisations came together in February 2014 to launch the Global Health Security Agenda (GHSA) to assist countries to develop and meet their IHR capacities for 'a world safe and secure from infectious disease threats'.

The GHSA is centred around three pillars of infectious disease: prevention (to preemptively protect against threats), detection (to determine when a threat arises) and

\footnotetext{
${ }^{154}$ Moon et al. (2015).

${ }^{155}$ Meier et al. (2020).

${ }^{156}$ World Health Organization, 'International Health Regulations (2005)' (2008) art. 44.

${ }^{157}$ Kerry et al. (2014).

${ }^{158}$ World Health Organization (2018).
} 
response (to address threats as they are occurring). ${ }^{159}$ Under these pillars are eleven 'action packages', or areas of specific focus, to give effect to these pillars of prevention, detection, and response. The action packages_-including, inter alia, preventing zoonotic diseases, ensuring biosafety and biosecurity, establishing real-time surveillance and developing medical countermeasures - set out targets, measurements, and specific action items for states to realise infectious disease control. National governments under the GHSA are urged to build their capacities to support these action packages, including through specific legislative and policy reforms. ${ }^{160}$

Despite the centrality of human rights to the revision of the IHR, and the opportunity to use the IHR implementation process to incorporate human rights protections into public health policies, the GHSA shifts away from an explicit consideration of human rights. The right to health is implicitly realised through the work of the GHSA, improving infectious disease surveillance and outbreak response capacities; however, the GHSA does not incorporate the lessons that led to the inclusion of human rights language in the revision of the IHR, such as the role of civil society, scientists, and the media as surveillance sources. ${ }^{161}$ The realisation of human rights is not expressly included at all in the text of the GHSA action packages. While the action packages require participating countries to implement policy reforms, there is no requirement that countries ensure that such reforms are consistent with human rights obligations under international health law or international human rights law. Many of the action packages will influence health-related human rights-on issues of surveillance and privacy rights, bodily integrity and freedom of movement, and interventions that may raise procedural rights issues-yet the GHSA includes no safeguards that such activities are conducted in ways that respect, protect, or fulfill human rights.

\subsection{The Securitisation of Infectious Disease and Implications for Human Rights}

Given the absence of explicit human rights language and obligations, the GHSA risks neglecting — or even undermining — the public health benefits of a rights-based approach to infectious disease prevent, detection, and response. Rather than the traditional public health paradigm, the GHSA is framed through a 'securitisation' approach to disease, which views threats to public health as existential threats to national and international security, 'requiring emergency measures and justifying actions outside the normal bounds of political procedure'. ${ }^{162}$ Conceptually, the process of securitising socio-economic issues is not inherently in conflict with human rights. For example, the concept of 'human security' arose from human rights-based

\footnotetext{
${ }^{159}$ Centers for Disease Control and Prevention (CDC) (2014).

${ }^{160}$ Meier et al. (2017).

${ }^{161}$ Davies (2017).

${ }^{162}$ Buzan et al. (1998); as cited in Elbe (2006).
} 
approaches to development. ${ }^{163}$ WHO has described global health security as addressing 'vulnerabilities to acute public health events', ${ }^{164}$ and this description is consistent with how international human rights law frames the right to health. However, global health security is rarely presented in current policy discourse through the lens of human rights. ${ }^{165}$ As seen in the modern history of infectious disease control-from HIV to Ebola to COVID-19-governments have used public health emergencies to rationalise limitations on, or in some cases derogations from, their obligations under international human rights law. Framing certain infectious diseases as risks to security can normalise what would otherwise be extraordinary measures, undermining the justifications behind necessary limitations of human rights under international law. Further, if an infectious disease arises that is deemed a threat to national or international security, there is a risk that primary decision-making authority can shift from public health decision-makers to national security institutions. ${ }^{166}$ For example, during the 2014-2016 Ebola outbreak in West Africa, the UN Security Council stepped into the realm of global health through the adoption of Resolution 2177, which determined that the 'unprecedented extent of the Ebola outbreak in Africa constitutes a threat to international peace and security'. ${ }^{167}$ This resolution highlighted the potential for 'forum shopping' global health threats-from health governance to security governance-leading to security-based policies that may conflict with health and human rights goals, as seen in autocratic emergency responses to COVID-19 that have drawn the scrutiny of the UN High Commissioner for Human Rights, public health professional societies, and human rights non-governmental organizations. ${ }^{168}$ Rather than supporting infectious disease control efforts, such conflicts can undermine effective collaboration between domestic public health and national security authorities responsible for the infectious disease response. ${ }^{169}$

The GHSA has demonstrated that the reframing of global public health as an international security issue has the power to mobilize high-income countries to invest financial and technical resources into capacity building for infectious disease prevention, detection, and response in low-income countries. Through the JEE process, more than sixty countries have undergone external evaluations of their IHR core capacity compliance to highlight gaps in capacities and set priorities for full IHR implementation. ${ }^{170}$ However, such a securitization approach funded by high-income countries

\footnotetext{
${ }^{163}$ Amon (2014b), 293.

${ }^{164}$ World Health Organization (2007).

${ }^{165}$ Amon (2014b), 293.

${ }^{166}$ Buzan et al. (1998); as cited in Elbe (2006), 119, 127-28.

${ }^{167}$ United Nations Security Council, 'Security Council resolution 2177 (2014) [on the outbreak of the Ebola virus in, and its impact on, West Africa]' 18 September 2014, S/RES/2177 (2014).

${ }^{168}$ Human Rights Watch. Human Rights Dimensions of COVID-19 Response (2020).

${ }^{169}$ Crawford et al. (2016).

${ }^{170}$ World Health Organization, 'Join External Evaluation (JEE) mission reports', available at: http:// www.who.int/ihr/procedures/mission-reports/en/.
} 
inherently prioritises threats to high-income countries. ${ }^{171}$ Neglected diseases or diseases that do not pose a security threat to wealthy nations are unlikely to trigger the financing and capacity building necessary for infectious disease governance, forcing low-income countries to rely solely on traditionally underfunded humanitarian approaches to some pressing infectious disease threats. The securitization approach imparts obligations on low-income countries that prioritises surveillance of emerging or re-emerging infectious diseases, which may not reflect the immediate public health priorities of that country. ${ }^{172}$ Despite this, the strengthening of public health systems for emerging or re-emerging diseases is hoped to have flow-on effects that benefit infectious diseases that do not fit within the securitisation paradigm. This was demonstrated in the reverse (i.e., humanitarian investment advancing health security) in Nigeria during the 2014-2016 Ebola epidemic, when polio surveillance and response systems were able to transform quickly to detect cases and conduct subsequent contact tracing, and now as Ebola surveillance and response systems are being repurposed for COVID-19 control. ${ }^{173}$

With the GHSA distorting political priority-setting in infectious disease governance, the securitisation of infectious disease further risks undermining rights-based approaches to health where emergency measures test the permissible limitations on human rights to protect public health. Through a securitisation lens, what would otherwise be an unauthorised limitation of a right may be legitimised in circumstances where the legitimacy derives from emergency authorities. This risks removing infectious disease control from 'routine democratic considerations' ${ }^{174}$ in ministries of health or departments of public health to less transparent parts of government under police or military authorities. This securitisation of public health has been pervasive in the COVID-19 response. Inherent in the securitisation of public health is the risk that national security concerns drive a country's response to an infectious disease in ways that harm both human rights and public health. It is imperative that any risk that an infectious disease poses to the economic or political integrity of the nation does not override parallel risks to human rights. This balance between infectious disease control and human rights realisation in the context of a pandemic was carefully examined in the drafting of the IHR; however, countries that have not implemented human rights frameworks under law-whether constitutional, legislative, or regulatory_risk implementing infectious disease prevention, detection, and response without these important rights-based safeguards.

The IHR brought human rights explicitly into the realm of global governance for infectious diseases. While implementation of the IHR's traditional public health core competencies has been the focus of programmes to accelerate domestic implementation, greater attention must be paid to ensuring the implementation of the IHR's human rights provisions. To re-centre and reiterate human rights protections within

\footnotetext{
${ }^{171}$ Davies (2008), 295, 298-302.

${ }^{172}$ Ibid., 309.

${ }^{173}$ Vaz et al. (2016).

${ }^{174}$ Elbe (2006), 119, 127.
} 
global health law, it will be necessary to continue to recognise the inextricable linkages between human rights and public health. As seen in the limited influence of rights-violating efforts to contain and mitigate the COVID-19 pandemic, it remains clear that the lack of respect for human rights in a global health security response can hobble efforts to prevent, detect, and respond to infectious disease. ${ }^{175}$ Correspondingly, the realisation of human rights principles - including non-discrimination, participation, transparency, and accountability-remain critical for an effective public health response that ensures the highest attainable standard of health.

\section{Conclusion}

Notwithstanding the robust development of international human rights frameworks to codify health-related human rights, it remains uncertain whether human rights will continue to influence infectious disease control. Assuring the continuing realisation of human rights - even amidst this unprecedented COVID-19 pandemic responseit will be necessary to assess whether infection control policies, programmes, and practices pose the least threat of infringing on human rights while presenting the greatest opportunity to realise health-related human rights. Human rights scholars can provide this human rights impact assessment as a basis to monitor infectious disease control actions in national health policy and global health governance. There must be accountability for human rights in national policy and global governance, codified through the adoption of: interpretive general comments on infectious disease control from human rights treaty bodies; WHO human rights guidance for IHR implementation that is assessed through the IHR Review Process; and revised human rights derogation standards prepared by an independent body of experts, involving civil society, global health lawyers, and other public health experts in the field. Given that such human rights derogation and realisation must be assessed on a caseby-case basis, global governance systems can provide necessary assessments of state actions, recognizing the connections between national policy and global governance and facilitating human rights accountability in preventing, detecting, and responding to infectious disease through global health law.

\section{References}

Amon J (2014a) What turns a few cases of disease into thousands? Human Rights Watch. https:// www.hrw.org/news/2014/09/12/what-turns-few-cases-disease-thousands (12 Sept)

Amon JJ (2014b) Health security and/or human rights? In: Rushton S, Youde J (eds) Routledge handbook of global health security. Routledge

Annas G, Grodin M (1992) The Nazi doctors and the Nuremberg code: human rights in human experimentation. Oxford University Press, Oxford

${ }^{175}$ Amon (2014b), 293, 300. 
Baker MG, Fidler DP (2006) Global public health surveillance under new international health regulations. Emerg Infect Dis 12(7):1058-1062

Barondess JA (1996) Medicine against society: lessons from the Third Reich. JAMA 276(20):16571660

Barrett R, Kuzawa C, McDade T, Armelagos G (1998) Emerging and re-emerging infectious diseases: the third epidemiologic transition. Annu Rev Anthropol 27:247-271

Bayer R (1991) Public health policy and the AIDS epidemic. An end to HIV exceptionalism? N Engl J Med 324(21):1500-1504

Bayer R, Healton C (1989) Controlling AIDS in Cuba. N Engl J Med 320(15):1022-1024

Beaglehole R, Bonita R (1997) Public health at the crossroads: achievements and prospects. Cambridge University Press, Cambridge

Brockington F (1968) World health, 2nd edn. Churchill Livingstone, Harcourt Brace, p 131

Buzan B, Wæver O, de Wilde J (1998) Security: a new framework for analysis. Lynne Rienner Publishers, Boulder

Centers for Disease Control and Prevention (CDC) (2003) Efficiency of quarantine during an epidemic of severe acute respiratory syndrome-Beijing, China, 2003. MMWR Morb Mortal Wkly Rep 52(43): 1037

Centers for Disease Control and Prevention (CDC) (2014) Global health security agenda: action packages. CDC. https://www.cdc.gov/globalhealth/healthprotection/ghs/pdf/ghsa-actionpackages_24-september-2014.pdf

Champion VL, Skinner CS (2008) The health belief model. In Glanz K, Rimer BK, Viswanath K (eds) Health behavior and health education. Jossey-Bass, pp 45-65

Childress JF, Bernheim RG (2003) Beyond the liberal and communitarian impasse: a framework and vision for public health. Fla Law Rev 55(5):1191-1193

Commission on a Global Health Risk Framework for the Future (2016) The neglected dimension of global security: a framework to counter infectious disease crises. National Academies Press

Crawford R, Rutz D, Evans DP (2016) "Between Combat Boots and Birkenstocks"-lessons from HIV/AIDS, SARS, H1N1 and Ebola. Public Health 141:186-191

Curran WJ, Clark ME, Gostin L (1987) AIDS: legal and policy implications of the application of traditional disease control measures. J Law Med Ethics 15(1-2):27-35

Davies SE (2008) Securitizing infectious disease. Int Aff 84(2):295-313

Davies SE (2017) Infectious disease outbreak response: mind the rights gap. Med Law Rev 25(2):270-292

De Bode L (2015) WHO wants sanctions against countries for mishandling epidemic. Al Jazeera America. http://america.aljazeera.com/articles/2015/10/22/health-sanctions-againstcountries-misguided.html (22 Oct)

De Oliveria Chiang ED, Baker ML, Figueroa-Downing D, Baggio ML, Villa LL, Neto JE, Hadley C, Bednarczyk RA, Evans DP (2015) "Those who love, vaccinate": parental perceptions of HPV vaccination. J Hum Growth Dev 25(3):341-350

del Rio C, Mehta AK, Lyon M III, Guarner J (2014) Ebola hemorrhagic fever in 2014: the tale of an evolving epidemic. Ann Intern Med 161:746-748

Donnelly J (1982) Human rights and human dignity: an analytic critique of non-Western conceptions of human rights. Am Polit Sci Rev 76(2):303-316

Donnelly J (2003) Universal human rights in theory and practice, 2nd edn. Cornell University Press, London

Ebola Interim Assessment Panel (2015) Report of the Ebola Interim Assessment Panel. World Health Organization, p 12. http://www.who.int/csr/resources/publications/ebola/report-by-panel. pdf?ua $=1$ (7 July)

Eckholm E (2003) China threatens execution in intentional spreading of SARS. The New York Times. https://www.nytimes.com/2003/05/15/international/asia/china-threatens-executionin-intentional-spreading-of.html (15 May)

Elbe S (2006) Should HIV/AIDS be securitized? The ethical dilemmas of linking HIV/AIDS and security. Int Stud Q 50(1):119-144 
Fee E, Parry M (2008) Jonathan Mann, HIV/AIDS, and human rights. J Public Health Policy 29(1):54-71

Felner E (2009) Closing the "Escape Hatch": a toolkit to monitor the progressive realisation of economic, social, and cultural rights. J Hum Rights Pract 1:402-404

Fidler DP (2002) A globalized theory of public health law. J Law Med Ethics 30(2):150-156

Fidler D (2003) SARS and international law. ASIL Insights 8(7)

Figueroa-Downing D, Baggio ML, Baker ML, De Oliveria Chiang ED, Villa LL, Neto JE, Evans DP, Bednarczyk RA (2016) Factors influencing HPV vaccine delivery by healthcare professionals at public health posts in São Paulo, Brazil. Int J Gynecol Obstet 136(1):33-39

Fleck F (2003) How SARS changed the world in less than six months. Bull World Health Organ 81(8):625-626

Giliomee H, Mbenga B (2007) New history of South Africa, 1st edn. Tafelberg Publishers, Cape Town

Gill B (2003) China and SARS: lessons, implications and future steps: presentation to the Congressional-Executive Commission on China. CECC. http://www.cecc.gov/sites/ chinacommission.house.gov/files/documents/roundtables/2003/CECC\%20Roundtable\% 20Testimony\%20-\%20Bates\%20Gill\%20-\%205.12.03.pdf

Godlee F, Pakenham-Walsh N, Ncayiyana D, Cohen B, Packer A (2004) Can we achieve health information for all by 2015? Lancet 364(9430):295-300

Gostin LO (2001) Public health, ethics, and human rights: a tribute to the Late Jonathan Mann. J Law Med Ethics 29(2):121-130

Gostin LO (2014) Global health law. Harvard University Press, Cambridge

Gostin LO, Katz R (2016) The International Health Regulations: the governing framework for global health security. Milbank Q 94:264-266

Gostin L, Lazzarini Z (1997) Human rights and public health in the AIDS pandemic. Oxford University Press, Oxford

Gostin L, Mann J (1994) Towards the development of a human rights impact assessment for the formulation and evaluation of health policies. Health Hum Rights 1(1):58, 70-71

Gruskin S, Hendriks A, Tomasevski K (1996) Human rights and responses to HIV/AIDS. In: Mann J, Tarantola D (eds) AIDS in the World II: global dimensions, social roots, and responses. Oxford University Press, Oxford

Gruskin S, Mills EJ, Tarantola D (2007) History, principles, and practice of health and human rights. Lancet 370(9585):449-455

Gust D, Darkling N, Kennedy A, Schwartz B (2008) Parents with doubts about vaccines: which vaccines and reasons why. Pediatrics 122(4):718-725

Habibi R et al (2020) Do not violate the international health regulations during the COVID-19 Outbreak. Lancet 395(10225):664-666

Hoffman SZ (2004) HIV/AIDS in Cuba: a model for care or an ethical dilemma? Afr Health Sci 4(3):208-209

Holland S (2015) Public health ethics. Polity Press, Cambridge

Howard-Jones N (1975) The scientific background of the international sanitary conferences. World Health Organization. http://apps.who.int/iris/bitstream/10665/62873/1/14549_eng.pdf

Huang Y (2004) The SARS epidemic and its aftermath in China: a political perspective. National Academies Press, Washington, D.C.

Institute of Medicine (2003) Unequal treatment: confronting racial and ethnic disparities in health care. The National Academies Press, Washington, D.C.

Kerry J, Sebelius K, Monaco L (2014) Why global health security is a national priority. CNN. http:// www.cnn.com/2014/02/12/opinion/kerry-sebelius-health-security/index.html (12 Feb)

King S (1999) Vaccination policies: individual rights v. community health. Br Med J 319(7223)

Kirby M (1988) The new AIDS virus—ineffective and unjust laws. J Acquir Immune Defic Syndr 1(3):304-305

Koenig S, Léandre F, Farmer PE (2004) Scaling-up HIV treatment programmes in resource-limited settings: the rural Haiti experience. AIDS (Lond) 18:S21-S25 
Larson H, de Figueiredo A, Xiahong Z, Schulz W, Verger P, Johnston I, Cook A, Jones N (2016) The state of vaccine confidence 2016: global insights through a 67-country survey. EBioMedicine 12:295-301

Lippman M (1992) The other Nuremberg: American prosecutions of Nazi war criminals in occupied Germany. Indiana Int Comp Law Rev 3(1):1-22

Lippman M (1993) The Nazi doctors trial and the international prohibition on medical involvement in torture. Loyola Los Angeles Int Comp Law J 15(2):395-406

Lyon M, Mehta A, Varkey JB, Brantly K, Plyler L, McElroy A, Kraft C et al (2014) Clinical care of two patients with Ebola virus disease in the United States. N Engl J Med 371:2402-2409 (18 Dec)

Mahajan AP, Sayles J, Patel VA, Remien RH, Sawires SR, Ortiz DJ, Szekeres G, Coates TJ (2008) Stigma in the HIV/AIDS epidemic: a review of the literature and recommendations for the way forward. AIDS (Lond Engl) 22(Suppl 2):S67

Malinowski MJ (2003) Choosing the genetic makeup of children: our eugenics past, present, and future? Conn Law Rev 36(1):125, 152-154

Mann J (1992) AIDS: the second decade: a global perspective. J Infect Dis 165(2):245-250

Mann J (1996) Health and human rights. Br Med J 312(7036)

Mann J (1999) Human rights and AIDS. In: Mann J, Gruskin S, Grodin M, Annas G (eds) Health and human rights: a reader. Routledge, New York

Mann J, Tarantola D (1998) Responding to HIV/AIDS: a historical perspective. Health Hum Rights 2(4):5-8

Mann J, Gostin L, Gruskin S, Brennan T, Lazzarini Z, Fineberg H (1999) Health and human rights. In: Mann J, Gruskin S, Grodin M, Annas G (eds) Health and human rights: a reader. Routledge, New York

Marineli F, Tsoucalas G, Karamanou M, Androutsos G (2013) Mary Mallon (1869-1938) and the history of typhoid fever. Ann Gastroenterol 26(2)

Mariner WK, Annas G, Glantz LH (2005) Jacobson v Massachusetts: it's not your great-greatgrandfather's public health law. Am J Public Health 95(4):581-590

Marks SP (2001) Jonathan Mann's legacy to the 21st century: the human rights imperative for public health. J Law Med Ethics 29(2):131-136

Marks S (2004) The human right to development: between rhetoric and reality. Harvard Hum Rights J 17:137-138

McCarthy M (2015) Measles outbreak linked to Disney theme parks reaches five states and Mexico. Br Med J 350

McDougal MS, Lasswell HD, Chen L (1980) Human rights and world public order: the basic policies of an international law of human dignity. Yale University Press, p 29

McNeil DG Jr (2014) Using a tactic unseen in a century, countries cordon off Ebola-racked areas. The New York Times. https://www.nytimes.com/2014/08/13/science/using-a-tactic-unseen-in-acentury-countries-cordon-off-ebola-racked-areas.html?mcubz=1 (12 Aug)

Meier BM (2006) Employing health rights for global justice: the promise of public health in response to the insalubrious ramifications of globalisation. Cornell Int Law J 39(3):711-778

Meier BM, Mori LM (2005) The highest attainable standard: advancing a collective human right to public health. Columbia Hum Rights Law Rev 37(1):101-147

Meier BM, Pardue C, London L (2012) Implementing community participation through legislative reform: a study of the policy framework for community participation in the Western Cape province of South Africa. BMC Int Health Hum Rights 12(1):15

Meier BM, Tureski K, Bockh E, Carr D, Ayala A, Roberts A, Cloud L, Wilhelm N, Burris S (2017) Examining national public health law to realize the global health security agenda. Med Law Rev 25(2):240-243

Meier BM, Habibi R, Yang YT (2020) Travel restrictions violate international law. Science 367:1436

Moon S, Sridhar D, Pate M, Jha A, Clinton C, Delaunay S, Edwin V et al (2015) Will Ebola change the game? Ten essential reforms before the next pandemic. The report of the Harvard-LSHTM Independent Panel on the Global Response to Ebola. Lancet 386(10009):2204-2221 
Moyn S (2010) The last utopia: human rights in history. Harvard University Press, Cambridge

Omer SB (2015) How to handle vaccine skeptics. New York Times. https://www.nytimes.com/ 2015/02/06/opinion/how-to-handle-the-vaccine-skeptics.html?_r=0 (6 Feb)

Omer SB, Pan WKY, Halsey NA (2006) Nonmedical exemptions to school immunisation requirements: secular trends and association off state policies with pertussis incidence. JAMA 296(14): 1757-1763

Omer SB, Richards JL, Bednarczyk RA (2012) Vaccination policies and rates of exemption from immunisation, 2005-2001. N Engl J Med 367:1170-1171

Onishi N (2014) Quarantine for Ebola lifted in Liberia slum. The New York Times. https://www. nytimes.com/2014/08/30/world/africa/quarantine-for-ebola-lifted-in-liberia-slum.html (29 Aug)

Pannenborg CO (1979) A New International Health Order: An Inquiry into the International Relations of World Health and Medical Care. Sijthoff \& Noordhoff, Alphen aan den Rijn, The Netherlands

PBS Frontline (2006) Haiti, the high price of stigma. PBS Frontline: The Age of AIDS. http://www. pbs.org/wgbh/pages/frontline/aids/countries/ht.html

Potts H (2008) Participation and the right to the highest attainable standard of health. University of Essex

Preston J (2009) Obama lifts a ban on entry into U.S. by H.I.V.-positive people. New York Times. http://www.nytimes.com/2009/10/31/us/politics/31travel.html (30 Oct)

Price PJ (2015) Ebola and the Law in the United States: a short guide to public health authority and practical limits. Emory Legal Studies Research Paper No. 14-299. https://ssrn.com/abstract= 2538187

Raeburn J, Macfarlane S (2003) Putting the public into public health: towards a more people-centred approach. In: Beaglehole R (ed) Global public health: a new era. Oxford University Press, pp 243-245

Reed G (2011) The human dimension of AIDS in Cuba: Jorge Perez MD, MS Director, Pedro Kourí Tropical Medicine Institute. MEDICC Rev 13(2):14-19

Rhodes T, Singer M, Bourgois P, Friedman S, Strathdee S (2005) The social structural production of HIV risk among injecting drug users. Soc Sci Med 61(5):1026-1044

Rose G, Navarro V, Krieger N, Zierler S (1999) Population perspective. In: Beauchamp DE, Steinbock B (eds) New ethics for the public's health. Oxford University Press, Oxford

Rosen G (1974) From medical police to social medicine: essays on the history of health care. Science History Publications, New York

Roush S, Murphy T, The Vaccine-Preventable Disease Table Working Group (2007) Historical comparisons of morbidity and morality for vaccine-preventable disease in the United States. 298(18):2155-2163

Ryle JA (1948) Changing disciplines: lectures on the history, method, and motives of social pathology. Oxford University Press, Oxford

Saha S, Komaromy M, Koepsell TD, Bindman AB (1999) Patient-physician racial concordance and the perceived quality and use of health care. Arch Intern Med 159(9):997-1004

Sand R (1934) L'Économie humaine par la médicine sociale. Rieder, Paris

Sidel VW (1996) The social responsibilities of health professionals: lessons from their role in Nazi Germany. JAMA 276(20):1679

Slaughter A-M (1997) The real new world. Foreign Aff 76:183-184

Steiner HJ, Alston P, Goodman R (2008) International human rights in context: law, politics, morals, 3rd edn. Oxford University Press, Oxford

Taylor T (1992) Opening statement of the prosecution, December 9, 1946. In: Annas G, Grodin M (1992) The Nazi doctors and the Nuremberg code: human rights in human experimentation. Oxford University Press, Oxford

Taylor AL (2004) Governing the globalization of public health. J Law Med Ethics 32:500-501

Taylor A (2014) Why are Australia and Canada following North Korea's lead on Ebola? Washington Post. https://www.washingtonpost.com/news/worldviews/wp/2014/11/06/why-are-australiaand-canada-following-north-koreas-lead-on-ebola/?utm_term=.b1efeb356ecc (6 Nov) 
The Institute of Medicine (1988) The future of public health. The National Academies Press, Washington, D.C.

United States Congressional-Executive Commission on China (CECC) (2003) Information control and self-censorship in the PRC and the spread of SARS. CECC. https://www.cecc.gov/ publications/issue-papers/information-control-and-self-censorship-in-the-prc-and-the-spreadof-sars

VanderWal K (1990) Collective human rights: a Western view. In: Bertin J, Baeher P, Herman Burgers J, Flinterman C, de Klerk B, Kroes R, van Minnen CA, VanderWal K (eds) Human rights in a pluralist world: individuals and collectivities. Meckler, London

Vaz RG, Mkanda P, Banda R, Komkech W, Ekundare-Famiyesin OO, Onyibe R, Abidoye S et al (2016) The role of the polio program infrastructure in response to Ebola virus disease outbreak in Nigeria 2014. J Infect Dis 213(Suppl 3):S140-S146

Werner D, Thuman C, Maxwell J (1992) Where there is no doctor: a village health care handbook. Hesperian Press

World Health Organization (1958) The first ten years of the World Health Organization. World Health Organization, Geneva

World Health Organization (1988) AIDS prevention and control: invited presentations and papers from the World Summit of Ministers of Health on Programmes for AIDS Prevention. World Health Organization and Pergamon Press

World Health Organization (2007) The world health report 2007-a safer future: global public health security in the 21st century. World Health Organization, Geneva

World Health Organization (2009) No rationale for travel restrictions. World Health Organization. http://www.who.int/csr/disease/swineflu/guidance/public_health/travel_advice/en/ (1 May)

World Health Organization (2014) Statement on the 1st meeting of the IHR Emergency Committee on the 2014 Ebola outbreak in West Africa. World Health Organization. http://www.who.int/ mediacentre/news/statements/2014/ebola-20140808/en/ (8 Aug)

World Health Organization (2016) Global tuberculosis report 2016. World Health Organization. http://apps.who.int/iris/bitstream/10665/250441/1/9789241565394-eng.pdf?ua=1

World Health Organization (2018). IHR (2005) Monitoring and evaluation framework: Joint External Evaluation tool (JEE tool) second edition. WHO, Geneva

Yang YT, Barraza L, Weidenaar K (2015) Measles outbreak as a catalyst for stricter vaccine exemption legislation. JAMA 314(12):1229-1230

Zidar A (2015) WHO International Health Regulations and human rights: from allusions to inclusion. Int J Hum Rights 19:505-526 